\title{
The construction of a post-academic university: Opportunity or status quo?
}

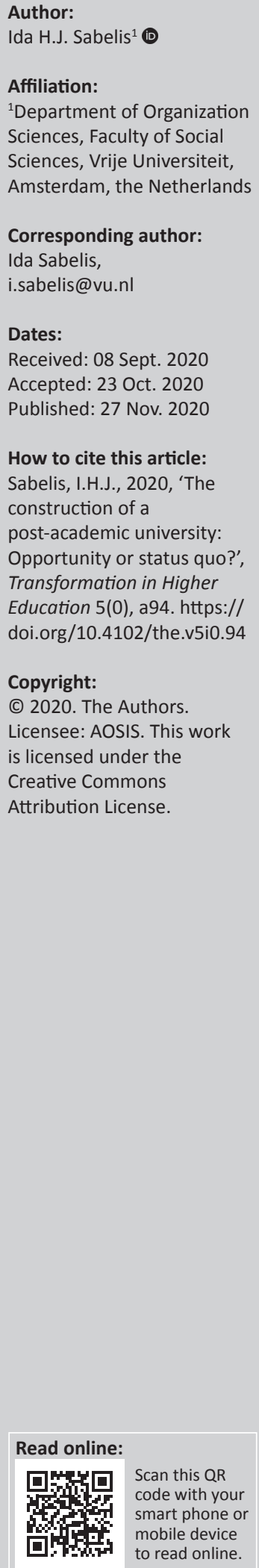

Background: Over the last two decades it has become increasingly urgent to rethink current hurdles and opportunities for higher education, not just in the Global North, but in the effects of Northern policies globally.

Aim: For the last 6 years a team of European scholars worked on a book entitled, Academia in Crisis (Donskis et al. 2019), AiC as it will be referred to in the article, inspired by the works of our late colleagues Zygmunt Bauman and Leonidas Donskis.

Setting: Tamara Shefer from the University of the West Cape (UWC) was invited to provide a foreword to $A i C$, providing a perspective from the Global South.

Method: This served to question underlying dimensions of mutual influence: neo-coloniality in times where the demand for decolonization from South African colleagues is strong and justified.

Results: It seems urgent, in the light of recent cooperation and mutual support between these two parts of the world, to reflect on recent developments in and around higher education. What currently 'neo-colonises' higher education? More or less parallel to $\mathrm{AiC}$, Rob Pattman and Ronelle Carolissen produced Transforming Transformation in 2018 with the promising subtitle 'South African offerings'.

Conclusion: Combining insights from those two works leads to renewed inspiration, at least in terms of new debates and questions about the present and future of higher education, especially following the current pandemic with all the effects it has had on collegial cooperation, locking down of universities, and perhaps some thinking time over managerialisms and other power processes in academic work.

Keywords: Europe; South Africa; higher education; post-academic university; neoliberal systems; decolonial; alternatives; transformation; post-pandemic university.

Excellence itself has been reduced to statistical accountancy. (Mbembe 2015:8)

\section{Introduction}

Much has been written in the wake of universities changing from knowledge institutes to education-producing entities under neoliberal conditions - from Birnbaum's How Colleges Work (1989) via the ironic concept of McUniversity (Parker \& Jary 1995; Ritzer 1996) all the way to Nelson's No University Is an Island (2011), both of which are more or less activist and meekly despairing works on the quality, and thus the future, of academia in international and national contexts (Flikkema 2016; Lorenz 2012; Shefer 2019a; Sobuwa \& McKenna 2019). By and large the growing hegemony of neoliberalism, that is, the belief that all organisations and institutions ultimately could thrive on market-economy principles, followed up by the consecutive 'privatisation' of healthcare, public transport and education, has produced some unintended effects, to put it mildly. And now that the coronavirus disease 2019 (Covid-19) pandemic has occupied centre stage, bringing traveling and conferencing to a halt, perhaps this pandemic will bring things to a standstill, enabling us to contemplate more acutely our ways ${ }^{1}$ and show us the limits of our ever-expanding industrial method of producing academic knowledge and education.

In this reflective article based on Academia in Crisis (AiC), I propose to explore issues in higher education from the perspectives embedded in the European tradition (and increasingly the Anglo-

1.I use "we' and 'our' where I mean 'the academic community I am part of: we, academics, or university employees. This is a tricky way to go about it, but further on it becomes clear that 'we' as academic community are part of the TINA developments in academia. The neoliberal developments in universities have led to protest and critique, but by and large, there was... no alternative, not even for those who predicted the commercialisation and commodification of higher education. 
Saxon-infused traditions to begin with), not least because its influence can be considered to have a neo-colonial stance on academia worldwide, and maybe invasively so in the Global South. We will be reflecting then on the transformation of 'academia', that is, on knowledge production, reflection and critical thinking infusing education. Next, we will look at international (global) scholarship via the 'uniformisation' of educational structures and calendars. Subsequently, we will study how it has increased the colonisation of the lifeworld of academics and lecturers via overwork and time pressures. And, finally, from a specific angle, we will present its impact on (new) ways of class-related and diversity-enhancing effects that could bring about different access options for students from different backgrounds, under the paradoxical idea that education-for-all might bring about societal change. These effects feature in $\mathrm{AiC}$, as it was written from a European context. For a non-European, more global readership, however, other questions should necessarily be raised from, and perhaps in contrast to, those insights. Thus, it seems important to include reflections on higher education and the position of universities from elsewhere, particularly those reflections inspired by the global call for 'decolonisation' and transformation of education as exemplified in the recent volume by Rob Pattman and Ronelle Carolissen, Transforming Transformation (2018), and inspired by the works of Mbembe (2015), Tate and Page (2018), Sobuwa and McKenna (2019) and others. This kind of reflection is usually done in terms of structures and systems. Yet, more specifically, it should also include the potential of bringing about change towards a genuinely democratic, that is, an inclusive, socially just and societally relevant, view on education. By looking at what is hindering academics (and students, cf. Kamsteeg 2016) from achieving their potential, as well as by acknowledging the need for decolonisation, along with looking at what we have in common (critique), and where or how we differ (neo- and decolonisation), might be able to bring about mutual collaborative thinking in order to feed a critical view on how we position ourselves in global academic work. More importantly, by striving for debates and conversations between the respective academic traditions and needs, this ultimately should lead to genuine transformation for all regions.

\section{Academia's crises}

What has happened with higher education in Europe over, say, the last three decades, and how has this influenced academic habits and rules elsewhere? In Europe, a marker for change was the 1999 'Bologna Treaty'2 in which the structure of higher education was 'uniformised' for the European Union (EU) countries, with the aim of providing education across borders and changing higher education so that the European ideal of Bildung, that is, a broad and critical, self-reflective mode of education, would again be revived, whilst at the same time establishing greater opportunities for international education (e.g. Abrahám 2019; Bianchini 2019). Obviously, in Europe, higher education is not really a matter

2.For the full text of the Declaration, visit: https://www.eurashe.eu/library/ bologna_1999_bologna-declaration-pdf/. of distant learning, as the continent is small enough to travel easily from one place to another, and 'in the old days' travelling for one's education was quite a common practice, not only on an academic level but also for a lot of professions (e.g. painters, builders and others - with differences from one of the then ruling kingdoms to another, of course) (Bauman \& Donskis 2013:135 ff.). Still, within the EU so many different timetables, accountability systems and management structures were in place that higher education systems were scarcely compatible. This implied that it did not really make sense for students to travel abroad to study, even in those cases where programmes were obviously better or only existed abroad. In the context of the growing pressure to shorten study times and become more 'efficient' in education, the Bologna Treaty offered the promise of open borders and more equal opportunities by claiming 'compatibility and comparability' (Louvain - Louvain la Neuve 2009) in higher education.

However, since the mid-1980s, another global capitalistdriven development was taking place on a wider scale and thus contextualising any innovation in the public sector: neoliberalisation, meaning the gradual industrialisation, financial accountability and increased control, accompanied by the Thatcherite expression 'there is no alternative' (TINA) (Bauman \& Donskis 2016). This driving force of sense-making in all realms of the public sector (worldwide, see below) has brought about a lot of the structures, systems, and social contracts that we now live and work by. Maybe unintentionally, TINA has become a symbolic marker and the core driver of control, especially in universities, as these have come to be seen as the embodiment of technological and practice-oriented, useful solutions. Furthermore, TINA fits the zeitgeist in an awkward way: it is nice to 'have no alternative', as this presupposes that straightforward solutions and rational options are out there, to be applied instantly, and, if not, 'science' will or will have to come up with the answers soon.

Was the Bologna Treaty partly meant to prevent the TINA effect from taking place? Or were both developments part of similar societal phenomena that represent our so-called 'liquid modernity', Zygmunt Bauman's (2000) symbolic term for making sense of postmodern times? Has reliance on old structures vanished in order to ultimately be replaced by new forms of ongoing control based on shifting configurations of identification? Bauman and Donskis' later work Moral Blindness (2013) confirms the dystopian undercurrents that transpired from a postmodern notion of our lifeworld. Not only in universities, but also on a far wider, global scale, the 'uniformisation of systems' needed to steer worldwide consumerist production and globalised reproduction.

Let us first have a look at how signals of alienation, separation ${ }^{3}$ and an increase in systems of accountability, control and measurability of just-about-everything have worked out.

3.Of formerly necessarily linked spheres, comparable to the loss of the 'social contract' (cf. Biesecker \& Von Winterfeld 2018). 
Obviously, this is necessarily an embarrassing process because as academics most of us have been part of that process; we have been compliant for a long time. Already around the turn of this century colleagues were speaking up against the growing managerialism in universities, but the soothing and seducing effect of organisational consultants explaining how and why common systems for measurement and quality control could only serve the collective striving for excellent science and education gave way to ever more 'uniformisation' of our trade. The promotion of 'fairness' in compatibility and comparability turned out to be a powerful discursive device to separate resistance from compliance. After all, who could say 'no' to quality control, accountability and a collective striving for excellence?

In the first two chapters of $A i C$, Leonidas Donskis and Frans Kamsteeg address exactly this development, leading to what can be called the post-academic university, a university that is ...

\begin{abstract}
... [A]n awkward amalgam of medieval academic ritual, specialisation, a blatant and blunt denial of the role of the humanities in modern society, managerialism ... (...) ... the playground for enormous pressures ... coming from technocratic forces disguised as the genuine voice of liberty and democracy ... with no room for the principle of alternative, including critical thought and self-questioning (Donskis et al. 2019:30).
\end{abstract}

Universities as institutes of education, in a very broad sense Bildung, have in Europe historically always navigated between deep thinking, the art of reflection and the production of knowledge to inspire, guide and provide instruments to 'serve society' as a whole. Yet, this is true perhaps more commonly for specific parts of societies via policies, politics and power tools. In our day and age, TINA has disrupted, at least partly, the multi-dimensional character of science and academia. A society that does not like, or claims not to need, 'alternatives' because certainty and palpable results are valued more seems to be looking for confirmation of 'no alternative'. This becomes clear, for instance, in the paradoxical wish for science to know all the answers and at the same time produce those within a set timeframe. A fine example of this twisted requirement is the emergence of state research bodies that divide up the scarce money for research. Apart from any general criticism about a state body taking over the responsibility for dividing scarce resources, the projects on offer by those bodies have begun to include fixed outcomes in terms of 'results' and 'usefulness', thereby tempting scientists to predict and produce results before a research project can even be carried out, including short-term calculated benefits. This latter preferably also occurs in terms of commodification of public-private partnerships. As a representative of my own country once said, reacting to a grant application that he really liked '... but now let us translate this fine project into economic terms. After all, we need to present research in terms of interest for our national big companies in order to make a real difference' ${ }^{4}$
Donskis in the context of the commercialisation of science talks about 'zombie concepts' (Atkinson 2007; Beck 2001; Donskis et al. 2019:32), referring to discursive devices that thrive and are being juggled mainly by university management and politicians. These concepts do not carry meaning anymore, and therefore have to be revised and reconstructed whilst critically rethinking meaning and impact. Think of autonomy, academic freedom, excellence and, lately, diversity or inclusion, and academic ethics. They become part of management and consultant speak, and finally appear in reports measuring performances and boost reputations in rat races between universities, whereas perhaps originally universities were there to jointly and collectively produce new knowledge, satisfy curiosity and serve collective societal needs via the benefit of education for all (Johnson 2006; Kamsteeg 2016). Reconstruction and revision of those concepts will require a critical look at the uses and application of those central concepts for university life, and perhaps a critical look at who benefits most from the lists and sheets where markers of 'excellence' are being counted and accounted for.

It almost goes without saying that the dream of internationally compatible university education from the Bologna Treaty has become co-opted and digested into management speak and the requirements of comparability in universities' administrative dungeons. Furthermore, the internationalisation of study programmes has materialised on paper and websites, but is still a difficult thing to do because of administrative jungles and shortening of study times, unless one has the funds to extend the time available for study. Yes, some institutes of liberal arts education have appeared, providing space for students to enter academic life via a broad range of topics and enabling them to peak into other fields rather than directly being geared towards their specific interests. University Colleges have popped up in many EU countries (Abrahám 2019; Bianchini 2019). However, practice has it that only a specific societal layer of students benefits; the advantaged are further advantaged, and vice versa. After all, spending 3 or 4 years in the luxury of transdisciplinary abundance is a costly thing. Consequently, this option is not obtainable for students who are, or have to be, goal-oriented towards a clear working environment or career perspective. Here is where class and other diversity issues come in. Meantime, it is generally known that the European (Rhineland) tradition does not favour the distinction between private and public schools, as does the Anglo-Saxon (the United Kingdom [UK] and the United States of America [USA]) tradition. The now almost global commercialisation of university education reinstates new class divisions, and undoubtedly strengthens race and gender divisions, especially in the Global South where education still is not as accessible in comparison to the Global North. ${ }^{5}$

\footnotetext{
and Ethiopia'. 2014-2018, Dr Lorraine Nencel and Dr I. Sabelis, Project Leaders. Include - NWO, the Netherlands.

5.Pattman and Carolissen (2018) - e.g. Chapters 12, 16, 18, 24, 27 - on the various societal positionings of students vis-à-vis inclusion in the university.
} 
This is not only related to shorter timeframes for studies and huge cohorts in the undergraduate phases, but also further on, in the extension of the curriculum. It becomes ever more common to plan a $\mathrm{PhD}$, or another post-doctorate study programme, right after a master's degree. Increasingly, the system of 'graduate schools' has entered universities, as if to suggest that the extension of the curriculum is necessary to build a career, suggesting that real science needs elite extension, whilst more likely hiding what has been rationalised out of traditional programmes (and the timeframes in which people were supposed to study). The design and structuration of study programmes demonstrates that efficiency, that is, a smooth programme, preferably to be finalised in a 'set time', is of core importance, more important than ever before. Apart from being related to the system of output finance for universities (finance is dependent on the diplomas obtained more than on actual student participation and performance), efficiency as a core value in university management leads to compression of space, time and people, just like everywhere else in industrial cultures.

The latter, that is, efficiency, also shapes the work of academics, or rather those who do the teaching. Increasingly, their tasks are extended with additional administrative tasks mainly serving accountability devices, coupled with precariousness in their working conditions, which take up about $40 \%$ of their time. ${ }^{6}$ In the Netherlands, some universities face increasing percentages of flexible personnel, especially in academic positions, ${ }^{7}$ leading to uneven division of age groups over the teaching community, and especially to patchwork contracts for younger people who sometimes have to work extremely hard without knowing if they will ever obtain any job certainty (Sabelis 2019). It seems only logical that the combination of work pressure, if not work stress, and precariousness in working conditions does not exactly help develop a critical attitude amongst young academics, mainly because only those who can and want to comply will survive within the system. What will that ultimately mean for the quality of research and education? What if slow thinkers and critical teachers have left academia in the near future when we will need them to escape uniform thinking? Bunn and Bennet (2020) summarise this:

\footnotetext{
... Present practices, value and pleasures in research, learning and teaching are directed toward 'keeping up' with others, always producing and anticipating change while at risk of being out-competed (for example, in employment and research opportunities) or becoming obsolete or irrelevant .... (p. 699)
}

One answer, to highlight once again the critical and creative thinking in the Rhineland-Bildung tradition, could be the cherishing of what is sometimes called 'slow science' (Berg \& Seeber 2016; Wels 2019) - a science that thrives on reflection, time for thought and, especially, not always knowing

6 .This is a personal observation after time keeping, also observed by colleagues - and a well-researched phenomenon (e.g. Clegg 2010; Menzies \& Newson 2007; Ylijoki 2013).

7.According to the Dutch Rathenau Institute (February 2020), more than half of universities' contracts are 'flexible', for example, not fixed but temporary in different combinations or patchwork arrangements. beforehand what the process will produce. And, according to Wels in AiC (2019:119 ff.), one of the markers of current developments is the loss of reading as a contemplative activity that helps us experience the combination of deep knowledge and time. In current academic life, the production of books, or monographs, has been replaced by a steady flow of journal articles. And journal articles are supposed to be published in high-ranking journals, internationally. In many countries, article publication has become more important than feeding research results back to communities, as I learned from the arrangements some South-East Asian colleagues have to live by. ${ }^{8}$ This happens not as a conscious choice but as an effect of managerialist organisation of both research and teaching processes. After all, in a competitive environment, we need measurements to be able to distinguish better research from the normal, and high performance from mediocre output. However, over the last two decades this has led to increasing output numbers, the measurement of journals according to standards largely outside the scope of their users, and the clogging of publication pipelines delaying publication times, instead of speeding up the spread of knowledge, in short, a form of 'temporal precarity' (Bunn \& Bennet 2020) that adds to the structural precarities already highlighted.

The non-democratic, and probably neo-colonising undercurrents, in these processes are clear to most colleagues. Sometimes one sees minor results puffed up in order to meet the next publication deadline, instead of working on a book development over several years so as to build a full and nuanced picture of a field, a problem, or a development or a well-wrought solution. 'Uniformisation' of publication opportunities does not necessarily lead to higher quality. And, at the end of the day, huge numbers of articles do not really enable an overview in any field; we plainly do not have the time to read everything published on a topic that interests us, provided that we have access to all the outlets in the first place. This paradoxical development at first sight triggers the plea to 'slow down', for contemplation and taking it slow, for being reflective, and thinking things over. However, as long as the underlying systemic causes are not addressed, slowing down will only lead to backlash in the rat race of academic performance. The exception, perhaps, lies in those senior colleagues who, after retirement and retreat from the everyday bureaucratic business, finally can 'do what they really like': deep thinking and well-wrought writing. And so who does the teaching whilst seniors are publishing? The answer is usually younger colleagues who have become socialised into the system with big teaching loads, with the message being that if you are looking for normal working hours, the university is not the place to be. ${ }^{9}$

In summary, these developments, the increase of what is euphemistically termed practice orientation, the 'uniformisation'

8.This anonymous reference will have to do because of possible restrictions of those same National Funding Bodies, if more precise information is to be revealed (Private field notes 2018).

9. At the start of the academic year 2020-2021, in September 2020, students in the Netherlands painted 10000 pink squares on the pavement between the old university building in the centre of Utrecht and the new science area at the city border. They had calculated that overwork of academics adds up to 10000 extra hours per week. 
of teaching and research and the concomitant time pressures (because systems plainly do not include all tasks in working times) together demonstrate a changing position for academia in our societies, as post-academic production institutions managed like global businesses. Too often over the last couple of years, I have witnessed those bureaucratic systems spreading (or colonising, for that matter) on a global scale, with the consequence that we face 'uniformisation' of higher education across borders to the detriment of local knowledge, needs and skills. What about transformation then? Does this mean new forms of colonisation of the curriculum globally? How does this relate to calls for decolonisation (e.g.Jansen 2019; Mbembe 2015, 2016; Shefer 2019b)? That is a question I cannot answer; it needs discussion and contemplation by those who stand for education on all levels, and preferably more comparative conversations across borders.

\section{Colonisation/decolonisation, transformation and other questions}

Let me illustrate where I think we stand now with two inspiring quotes I derived from the foreword of Transforming Transformation by Rob Pattman and Ronelle Carolissen (eds. 2018) - with the promising subtitle 'South African offerings'! Indeed, this book speaks to me from the context of South Africa - and provides so much familiarity and parallel thought - whilst at the same time demonstrating that in the debates on a global scale, different issues are at stake and different voices need to be heard. There is a different fighting spirit - caught in the middle as universities in South Africa navigate between commodified and commercialised international academic life and the genuine, very palpable and important context of racism, neo- and de-colonisation, and the development of African science and voices in a context of forms of human violence that cry out for exactly the type of analysis we plead for. This context adds quite different dimensions to the necessity of decolonising, transforming, reflecting and changing systems of higher education, and of academe in general, whilst including creative, genuinely innovative and long-term research in the process. Looking in detail at intersectionalities of gender, race, class, language and other forms of positioning, the examples in Transforming Transformations provide a kaleidoscopic in-depth overview of all dimensions to be included and dealt with, as well as the different levels (managerial, pedagogical, training-wise and political) that feed into the debates 'on offer' - and show the amount of work to be done.

This only serves to bring the necessary debates closer and equally urgent, for both our contexts. It illustrates that, not just in Europe, nor just in South Africa, systematic exclusion is partly an unintentional consequence of the current state of universities

\footnotetext{
... We have, since 1994, produced more than twenty national reports on our size, shape, admissions profiles, capacity to provide accommodation, leadership and governance, funding, research priorities, teaching and learning priorities,
}

transformation and the broad mission we want to see the system adopting. Every single institution in the system has been examined, for various reasons, multiple times. (eds. Pattman \& Carolissen 2018ii)

I would like to add that it does not just follow up on 1994 as a historical moment in South Africa. It was around that time that the TINA model came to dominate just about worldwide and forever rendered higher education more a business than a safe place for learning and thinking. The inevitability of this is illustrated by the second quote dealing with those who tried to resist the development and were ridiculed and dismissed:

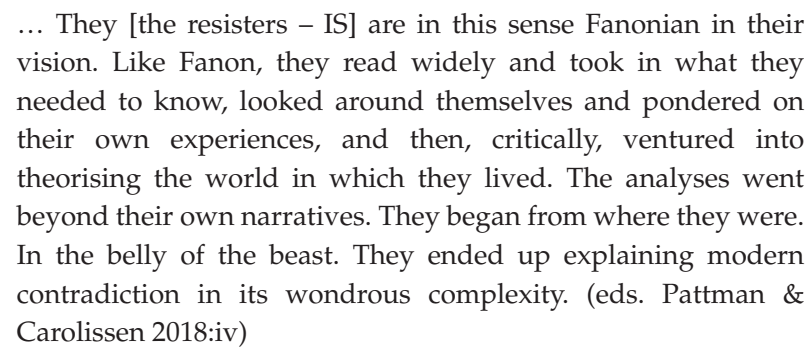

However, as we can see from the sum total of the chapters in Transforming Transformations, resistance is thriving on so many levels and from so many angles that the aftermath of TINA is not an easy situation to deal with. It will undoubtedly take time to balance the struggles involved not only from a geographical or global point of view but also in terms of weighing out dimensions of diversities (intersectionalities) more broadly against the interest of those who demand an immediate result.

Ultimately, of course, the question is, 'where do we go from here?' How can we escape from the dystopian undertone in this analysis of a culture of post-academic life (managerial research and teaching)? I have to admit that the South African contribution, Transforming Transformations, has a firm grounding in the daily lives of people - far more related to the lifeworld and the daily injustices experienced by ordinary people than the contemplative work of AiC. Will the South African critique, firmly rooted in an overall critique on academia from the position of decolonisation, bring about a greater sense of urgency to change? And at the same time, will the greater counting/accounting and jurisdiction than perhaps elsewhere (remember the example of South-East Asia) lead to more resistance and a plea for more local benefits from research and teaching alike? How come that in our countries the establishment of rules and monitoring systems continues to be seen, or at least promoted to be, a panacea to produce social justice and integrity in education?

\section{Reflections}

Now perhaps we can all agree that the ideal university does not exist, and perhaps should not exist if we are to take the ultimate consequence of decolonisation seriously. The very idea of 'ideal' renders difference obsolete, and kills discussion and reflection. Moreover, it would ultimately kill a lively, 
temporally/contemporarily fit idea of education in academia in terms of ongoing development and change. What binds us, however, and what we have in common, is the TINA flavour of how our universities are managed, producing regimes of counting/accounting, examination and comparability that hinder education instead of supporting it, and which include and co-opt all of us to such an extent that we seemingly cannot change or deflect that development. The point with TINA is that it is colonial (the 'no alternative' is framed from a Northern, capitalist point of view). Additionally, TINA also implies fixation on one system, which allows for no change whatsoever over time and across borders.

The main thing is that we find ourselves in a global movement towards measurements, and a specific understanding of justice and fairness (all measured the same, and geared towards ready-made solutions and efficiency, preferably) that excludes people's diversity in the first place. In Europe it has produced ivory towers, particularly from natural sciences' habits, whilst claiming to provide access for all. In South Africa it impedes decolonisation through its blind spot for the colonial undercurrent in promoting a globally uniform system. Underlying this are commodification, commercialisation, and especially rationalisation of control in Higher Education (HE) - be it because the business world calls for a specific type of employee, with very applicable skills and not too many questions, or be it because some groups of students claim the right of a diploma because they have paid regardless of their efforts. We face a non-recognition of human needs based on background variables that feed the up-or-out undercurrent in most educational systems in the world, or by fighting over who suffers most from the current system instead of unveiling new (and traditional) boundaries that separate us when we construct hierarchies when it comes to forms of exclusion. Are we thus facing a postacademic society or a post-university one, one where young people can just come and pick up their qualification, whilst thinking, debate and reflection need a new space, new niches to flourish, outside HE institutions? Or is it high time we just refuse to accept that we are functioning between bureaucratised systems and desperate students in neverending working days and weeks? Although some of this is just the reality we live in, the question is whether we should accept this as a future present. And, if we do not, what can we do?

\section{Dystopia and conversations}

I do not necessarily embrace a dystopic view of universities. In the European context, it might be sensible to have universities consider restructuring, for example, between professional, high-skill-based institutions versus other spaces for reflection from the angles of philosophy and preparation for research (like honours programmes and research masters at present). Obviously, both streams require accessibility for all, but choices, mentoring and selection should from the outset be based on motivation and career prospects, not on perceived status of diplomas with no consideration whatsoever for future prospects, individually as well as societally. I know this may sound elitist, but maybe we might just allow ourselves to be aware of, and try to counter, the unintended effects of 'university for all', for example, in ever bigger classes and inevitably in devaluation of diplomas over time. As for the South African context, I can only imagine that decolonisation requires a total rethink of all forms of education geared towards what is required in the South in general and in South Africa more specifically. Pattman and Carolissen's work provides a panoramic overview of interrelated fields that together demonstrate concern for social, economic, pedagogical and political dimensions that should be addressed in combination. It is not up to me to ponder this: the neo-colonisation of education already constitutes a risk when thinking about this. Debates over sociocultural and racial equality have a different stance, flavour and need in South Africa (Rudwick cited in eds. Pattman \& Carolissen 2018:489 ff.). Still, in mutual conversation it should be possible to detect how neo-colonial effects go hand in hand with resistance to transformation, and how in turn decolonisation and transformation also (should) inspire a rethink of curricula in the North.

Ultimately, this line of reasoning leads to the question of what education, in the cultural sense, is for, and with what timescales societies can and want to afford knowledge and professional development. Do knowledge and skill serve fast-food-like applicability? Do some societies more than others prefer techno-rational wealth over critical/political thinking? (cf. Guo \& Radder 202010). And should we perhaps also take a closer look at how new class relations come about through the 'higher education for all' ideal, causing higher student numbers, all whilst the resources cannot be sustained and all at the expense of those who work in the sector (cf. Sobuwa \& McKenna 2019)? The main implication seems to be that as long as we remain under the rule of neo-liberal production and business thinking in our institutions, not much will change. Young colleagues continue being selected based on their perseverance in managing huge classes/cohorts and on their capacity to comply with counting, journal article publishing and successful, that is, big-money grant applications. Yes, that is our world, and increasingly not a very attractive one for the brightest and the most creative amongst our students. Sometimes we find ourselves inclined to advise them then to opt for 'real business', because there you clearly know that production is what you are paid for. At the same time, let us indeed keep trying to expose the myth of how the content and practice of academia are indeed still colonial, not least because of the way academia more and more produces scholars who do not think in terms of themselves but in terms of the world of business and marketing. Despite the lip service paid to social justice in all dimensions,

10.Guo and Radder (2020) analyse the differences between Chinese and European attitudes towards the sciences, the latter aspiring to be more contemplative, the former traditionally/historically geared towards the production of practical solutions. 
it is our task to expose those discourses as protracting 'colonial' practices in HE. Perhaps it is time that we draw more on the ideas of our colleagues from South Africa and other postcolonial or globally marginalised spaces - in order to provide us with notions of decolonisation and transformation. To the extent that we can see these as watchwords, we can remind ourselves that there are options aside from TINA, away from a dystopic system. That type of transformation invites a critical rethink of the commodified mode that characterises a large part of global academia these days.

\section{Afterthought}

The current Covid-19 pandemic provides an almost cynical illustration of the long-term consequences of the TINA impact on academia. Where universities and research institutes have been forced into fierce competition over the last decades, all of a sudden they are required to join forces and collectively 'fight the pandemic'. Very often, in this situation of notknowing, this leads to competitive debates amongst scientists, revealing, on the one hand, how science works: a process of trial and error, and of deep debates, thinking and disagreeing. On the other hand, however, the development and production, for example, of a vaccine largely seems to be taking place in laboratories that have learnt to protect their own interests. They only collaborate with others (universities, institutes and global firms) after long negotiations over who benefits from what, and how, in terms of revenues and reputation. In the panic around stopping the pandemic and at the same time finding long-term solutions via a vaccine, countries are designing their own local policies, and scientists are having a hard time agreeing and sharing knowledge about what needs to be done.

The Covid-19 pandemic also has brought much of life to a standstill. Ironically, this global disaster may offer a golden opportunity to disrupt the globalised corporatisation of universities. Whilst travelling less (saving time!) and being confined to our homes, we end up inventing new ways of dealing with our everyday tasks, with the help of colleagues, worldwide or close by. On the one hand, some tasks now seem obsolete, like conferencing and producing one paper after the other. On the other hand, distance teaching and learning are finally serving TINA in an unexpected way. Although undoubtedly there are huge differences around the world, the switch to online communication brings about much extra time for preparation, re-scheduling and (finally?) learning to juggle with all the web-based options that were available already, but now have to be used. Apart from the attempt to force the old ways into new systems, we also have the unique chance to revise the status quo. Whilst some want to return to 'normal', some embrace the 'new normal' and see a chance to redesign patterns that have been hurting for some time. What if... we use our spare time to turn to a real transformation of higher education based on insight into the zombie concepts of excellence and performance? Do we have a choice between pursuing the further 'uniformisation' of curricula or do we seize the opportunity to rethink academia?
Working from our homes, wherever we are, now is the time for conversations, for meeting up with the 'offerings' that the debates over decolonisation and transformation bring.

\section{Acknowledgements}

The author would to acknowledge her dear late colleague Prof. Elda de Waal from North-West University, South Africa, who inspired the above contribution in lengthy talks about the future of our trade. And of course Tamara Shefer (UWC) served as a guiding angel for this piece through her dear friendship and ongoing critical capacity. Finally, the author would like to express her gratitude to Shan Simmonds and Petro du Preez (NWU) who were so patient and encouraging, waiting for the manuscript to finally materialise in writing. The author is enormously grateful to the anonymous reviewers who did a great job in scrutinising a previous version of the manuscript under, as always, huge time pressure.

\section{Competing interests}

The author has declared that no competing interest exists.

\section{Author's contributions}

I declare that I am the sole author of this research article.

\section{Ethical consideration}

This article followed all ethical standards for research without direct contact with human or animal subjects.

\section{Funding information}

This research received no specific grant from any funding agency in the public, commercial or not-for-profit sectors.

\section{Data availability}

Data sharing is not applicable to this article as no new data were created or analysed in this study.

\section{Disclaimer}

The views and opinions expressed in this article are those of the author and do not necessarily reflect the official policy or position of any affiliated agency of the author.

\section{References}

Abrahám, S., 2019, 'Liberal arts to the rescue of the bachelor's degree in Europe', in L. Donskis, I. Sabelis, F. Kamsteeg \& H. Wels (eds.), Academia in crisis. The rise and risk of neoliberal education in Europe, pp. 82-110, Leiden: Brill Rodopi.

Atkinson, W., 2007, 'Beck, individualization and the death of class: A critique 1', The British Journal of Sociology 58(3), 349-366. https://doi.org/10.1111/j.14684446.2007.00155.x

Bauman, Z., 2000, Liquid Modernity. Cambridge: Polity Press.

Bauman, Z. \& Donskis, L., 2013, Moral blindness: The loss of sensitivity in liquid modernity, Polity Press.

Bauman, Z. \& Donskis, L., 2016, Liquid evil, Cambridge: Polity Press.

Beck, U., 2001, 'Interview with Ulrich Beck', Journal of Consumer Culture 1(2), 261-277. https://doi.org/10.1177/146954050100100209 
Berg, M. \& Seeber, B.K., 2016, The slow professor: Challenging the Culture of Speed in the Academy, Toronto: University of Toronto Press.

Bianchini, S., 2019, 'Universities as laboratories. Internationalisation and the liquidity of national learning', in L. Donskis, I. Sabelis, F. Kamsteeg \& H. Wels (eds.) Academia in crisis. The rise and risk of neoliberal education in Europe, pp. 53-81, Leiden: Brill Rodopi.

Biesecker, A. \& Von Winterfeld, U., 2018, 'Notion of multiple crisis and feminist perspectives on social contract', Gender, Work \& Organization 25(3), 279-293. https://doi.org/10.1111/gwao.12206

Birnbaum, R., 1989, How colleges work: The cybernetics of academic organization and leadership, Jossey Bass, San Francisco, CA

Bunn, M. \& Bennett, A., 2020, 'Making futures: Equity and social justice in higher education timescapes', Teaching in Higher Education 25(6), 698-708. https://doi. org/10.1080/13562517.2020.1776247

Clegg, S., 2010, 'Time future - The dominant discourse of higher education', Time \& Society 19(3), 345-364. https://doi.org/10.1177/0961463X10381528

Donskis, L., Sabelis, I., Kamsteeg, F. \& Wels, H., 2019, Academia in crisis: The rise and risk of neoliberal education in Europe, Leiden: Brill Rodopi.

Flikkema, M., 2016, Sense of serving. Reconsidering the role of universities now, VU University Press, Amsterdam.

Guo, Y. \& Radder, H., 2020, 'The Chinese practice-oriented views of science and their political grounds', Zygon 55(3), 591-614. https://doi.org/10.1111/zygo.12635

Jansen, J. (ed.), 2019, Decolonisation in universities: The politics of knowledge, Johannesburg: Wits University Press.

Johnson, B., 2006, 'South African academia in crisis: The spread of "contrived collegia managerialism"', South African Journal of Higher Education 20(1), 58-71. https:// doi.org/10.4314/sajhe.v20i1.25558

Kamsteeg, F., 2016, 'Transformation and self-identity: Student narratives in postapartheid South Africa', Transformation in Higher Education 1(1), 1-10. https:// doi.org/10.4102/the.v1i1.10

Lorenz, C., 2012, 'If you're so smart, why are you under surveillance? Universities, neoliberalism, and new public management', Critical Inquiry 38(3), 599-629. https://doi.org/10.1086/664553

Louvain - Louvain-la-neuve, 2009, 'The Bologna Process 2020 - The European Highe Education Area in the new decade', Communiqué of the Conference of European Ministers Responsible for Higher Education, Leuven and Louvain-la-Neuve, 28th-29th April 2009.
Mbembe, A.J., 2015, 'Decolonizing knowledge and the question of the archive' Lecture delivered at the Wits Institute for Social and Economic Research, April 2015.

Mbembe, A.J., 2016, 'Decolonizing the university: New directions', Arts and Humanities in Higher Education 15(1), 29-45. https://doi.org/10.1177/1474022215618513

Menzies, H., \& Newson, J., 2007, 'No time to think: Academics' life in the globally wired university', Time \& Society 16(1), 83-98. https://doi.org/10.1177/0961463X07074103

Nelson, C., 2011, No university is an island: Saving academic freedom, vol. 4, New York: NYU Press.

Parker, M. \& Jary, D., 1995, 'The McUniversity: Organization, management and academic subjectivity', Organization 2(2), 319-338. https://doi. org/10.1177/135050849522013

Pattman, R. \& Carolissen, R. (eds.), 2018, Transforming transformation in research and teaching at South African Universities, Stellenbosch: African Sun Media.

Ritzer, G., 1996, 'McUniversity in the postmodern consumer society', Quality in Higher Education 2(3), 185-199. https://doi.org/10.1080/1353832960020302

Sabelis, I., 2019, 'Timescapes in academic life. Cubicles of time control', in L. Donskis, I. Sabelis, F. Kamsteeg \& H. Wels (eds.), Academia in crisis. The rise and risk of neoliberal education in Europe, pp. 129-149, Leiden: Brill Rodopi.

Shefer, T., 2019a, 'Introductory thoughts', in L. Donskis, I. Sabelis, F. Kamsteeg \& H Wels (eds.), Academia in crisis: The rise and risk of neoliberal education in Europe, pp. 1-10, Brill Rodopi.

Shefer, T., 2019b, 'Performative activism and activist performance: Young people engaging in decolonial feminist community psychology in contemporary South African contexts', in Boonzaier, F. \& Van Niekerk, T. (eds.) Decolonial feminist community psychology, pp. 143-154. Springer, Cham.

Sobuwa, S. \& McKenna, S., 2019, 'The obstinate notion that higher education is a meritocracy', Critical Studies in Teaching and Learning 7(2), 1-15. https://doi. org/10.14426/cristal.v7i2.184

Tate, S.A. \& Page, D., 2018, 'Whiteliness and institutional racism: Hiding behind (un) conscious bias', Ethics and Education 13(1), 141-155. https://doi.org/10.1080/17 449642.2018.1428718

Wels, H., 2019, 'Academia in the Fast Lane vs. Organisational Ethnography and the logic of slow food', in L. Donskis, I. Sabelis, F. Kamsteeg \& H. Wels (eds.), Academia in crisis. The rise and risk of neoliberal education in Europe, pp. 111-128, Leiden: Brill Rodopi.

Ylijoki, O.-H., 2013, 'Boundary-work between work and life in the high-speed university', Studies in Higher Education 38 (2), 242-255. https://doi.org/10.1080/ 03075079.2011.577524 